\title{
Is Trade Deindustrializing America? A Medium-Term Perspective
}

Free INTERNATIONAL TRADE rests on the principle of comparative advantage. By engaging in trade, a nation can benefit from specializing in the production of goods in which it is relatively more efficient and exchanging them for those in which other nations excel. Provided its cost levels are appropriately adjusted by exchange rate changes or monetary flows, the nation will be sufficiently competitive to pay for its import needs. Over time, comparative advantage may shift, however, and in principle an economy might lose its comparative advantage in an entire sector. Indeed, it is widely believed that the U.S. manufacturing sector is in the process of just such a decline-developed countries have become increasingly competitive with U.S. firms at the upper end of the technology spectrum while developing countries have penetrated the markets of those firms making more standardized products.

The perceived effect of international competition has grown to the point that it is frequently cited as the major source of structural change in the U.S. economy and the primary reason for the declining share of manufacturing in U.S. employment. This shift of U.S. production away

I am grateful to Kenneth D. Boese for excellent research assistance; and to Barry P. Bosworth, Edward R. Denison, Asim Erdilek, Carol Heim, Lawrence B. Krause, Joseph A. Pechman, members of the Brookings Panel, and participants of the Conference on the Political Economy of Inflation and Unemployment held at Williams College, October 1982, for comments. This study was partially funded by a grant from the Alex C. Walker Educational and Charitable Foundation. 
from manufacturing is viewed with some alarm, both because manufacturing activity is considered intrinsically desirable and because of the perceived adjustment costs associated with this shift. In addition, some argue that this decline in U.S. comparative advantage does not result from an inevitable process of technological diffusion or from changes in factors of production, but rather from the industrial and trade policies adopted by other nations. Without similar policies, some contend that the United States will eventually become a nation of farm products and services- "a nation of hamburger stands."

Before adopting policies based on these perceptions, it seems useful to take a careful look at the evidence. International trade is certainly not the only source of structural change in the U.S. economy. At least five factors have had important effects on the U.S. industrial base. First, the share of manufactured products in consumer spending has declined secularly because of the pattern of demand associated with rising U.S. income levels. Second, some of the long-run decline in the share of manufacturing in total employment reflects the relatively more rapid productivity growth in this sector. Third, because the demand for manufactured goods is highly sensitive to the overall growth rate of GNP, manufacturing production has been slowed disproportionately by the sluggish overall economic growth in the global economy since 1973. Fourth, shifts in the pattern of U.S. international specialization have arisen from changes in comparative advantage that, in turn, result from changes in relative factor endowments and production capabilities associated with foreign economic growth and policies. And fifth, shortrun changes in U.S. international competitiveness have come from changes in exchange rates and cyclical conditions both at home and abroad.

The appropriate choice of policies depends crucially on the ability to evaluate the relative impacts of these various factors on current U.S. industrial performance. If the slow rate of U.S. industrial growth is the inevitable result of world economic development, changes in international comparative advantage, or the post-1973 world economic malaise, special strategies to deal with such developments might be needed. If policies under the current world trading system are the reason, the United States might try to change that system or its own behavior within it. If exchange rate changes are important, factors such as the monetary- 
fiscal mix of policy or exchange-rate intervention policies might merit attention. If transitory cyclical forces are the cause, there might be no need for a new industrial policy but rather a change in macroeconomic policies or an acknowledgment that the slump brought on by current policies is the unavoidable cost of reducing inflation.

In this paper I concentrate on the effects of trade on employment and value added in manufacturing over the medium run. I use input-output analysis to distinguish shifts due to manufacturing trade from other sources of change. I report on estimates for fifty-two manufacturing industries, for the manufacturing sector in the aggregate, and for sectors aggregated by production process. I look briefly at developments of the past two years. But the sample period for most of the analysis ends in 1980 , partly for reasons of data availability and partly because I seek to emphasize the major structural change in U.S. industrial performance without having the data unduly affected by the recent recessions and exchange rate changes.

Given the radical changes in the world economy after 1973, the period from 1973 to 1980 is the most relevant sample for current policy discussions. The data for this period measure U.S. performance in the new international environment that is marked by stagflation, volatile exchange rates, and increasing government intervention in trade; and it is during this period, it is alleged, that foreign industrial policies have damaged the U.S. manufacturing base.

Observations for the 1973 to 1980 period, however, may be unduly influenced by the different cyclical positions prevailing in the endpoint years. Because capacity utilization in manufacturing was similar in 1970 and 1980, data for the entire decade are used to provide a second, cyclically neutral, measure of structural changes. ${ }^{1}$ Observations for 1970-80 are still influenced by changes in the real exchange rate of the dollar in these years. As measured by the International Monetary Fund, relative U.S. export prices for manufactured goods were 13.5 percent lower in 1980 than in 1970. In evaluating the results, therefore, it should be kept in mind that the U.S. trade performance during the 1970 s depended in part upon this price-adjustment process.

1. Capacity utilization in U.S. manufacturing, measured by the index of the Federal Reserve Board, was 79.3 percent in 1970 and 79.1 percent in 1980. 


\section{Foreign Trade and U.S. Manufacturing Output and Employment}

A separation of the effects on the economy of foreign trade and domestic forces begins with the identity $P=U+X-M$, where $P$ is production of goods; $U$, domestic use (consumption, government purchases, and investment including inventories); $X$, exports; and $M$, imports.

Using this identity and data on total production, exports, and imports, any change in production can be decomposed into a change due to domestic use and a change due to the foreign trade balance. But to estimate the impact of a change in one of the right-hand variables on individual domestic industries, or even its net impact on domestic production, the induced effects of that change must be estimated.

When an airplane is exported from the United States, for example, it embodies inputs such as aluminum, tires, computers, and so forth from a wide variety of other industries. Similarly, when an import replaces a domestic product, it reduces the demand in domestic manufacturing sectors that produce inputs for the affected domestic product. In some cases, the induced effects even change the allocation of total value added between domestic and foreign sources. For instance, an increase in some chemical exports will require an increase in imported oil as a raw material so that the net effect on total domestic production is less than the value of the export. A complete accounting of the impact of trade should incorporate these indirect effects.

The indirect effects of trade are estimated using the 1972 eighty-five sector input-output (I-O) table. Data on manufacturing output, exports, and imports for 1970,1972, 1973, and 1980, available at the four-digit Standard Industrial Classification (SIC) code level, are converted into 1972 dollars and arranged to correspond with the industrial coding structure of the fifty-two I-O manufacturing sectors used in this paper. ${ }^{2}$ Next the input-output table is used to estimate direct and indirect output requirements. Based on these requirements, estimates are then made of the proportions of total value added in each industry that could be related

2. I used the concordance provided by the Department of Commerce. See "Industry Classification of the 1972 Input-Output Tables," Survey of Current Business, vol. 59 (February 1979), p. 54. 
to (1) all manufactured goods exports, (2) manufactured goods estimated to be displaced by all manufactured goods imports, and (3) as a residual, the proportion of value added related to domestic use. Employment effects are estimated under the assumption that productivity growth in the exports and domestic products of each industry are identical, so that the allocation of employment to exports, imports, and domestic use corresponds to the allocation of value added. Because suitable trade deflators are not available, data on the current value of imports, exports, and output for each industry are deflated with the output deflators for each industry. ${ }^{3}$

Several limitations of this analysis should be noted. This is an exercise with ex post data rather than a simulation with a full-scale behavioral model. Thus when the model relates growth to domestic use, exports, and imports, it neither explains why the configurations occurred nor accounts for possible behavioral interactions among the endogenous variables. ${ }^{4}$ For example, growing competition from imports may have forced domestic producers to lower their prices. Consumption of both domestic products and imports might have increased as a result, but such effects are not examined. With the exception of modifications that were made to reflect changes in imported inputs, the input-output coefficients necessarily allow for no substitution possibilities among inputs and no change in input requirements over time. ${ }^{5}$ Furthermore, among products, the analysis assumes that final demands always substitute between particular imports and the output of the domestic industry that manufactures products similar to those imports rather than products

3. I implicitly assume a unitary elasticity of demand when applying this procedure to measure the import-competitive effects.

4. One attempt to incorporate such interactions is Gene M. Grossman, "The Employment and Wage Effects of Import Competition in the United States," Working Paper 1041 (National Bureau of Economic Research, 1982).

5. For each year the input-output matrix has been adjusted to account for imports used as intermediate inputs. All industries are assumed to use imports as intermediate inputs in the same ratio as the entire economy does. For example, if imports account for 10 percent of the domestic use of steel, it is assumed that the automobile industry uses imports for 10 percent of its steel needs. If one defines $m_{\mathrm{i}}$ as the ratio of imports to domestic use of industry $i$ and $r_{\mathrm{ij}}$ as the total requirement coefficient of commodity $i$ for final demand of commodity $j$, then for each year studied, one can construct a "total domestic requirements" matrix by replacing $r_{\mathrm{ij}}$ with $\left(1-m_{\mathrm{i}}\right) r_{\mathrm{ij}}$ if $i \neq j$ and with $1+\left(1-m_{\mathrm{i}}\right)\left(r_{\mathrm{ij}}-1\right)$ if $i=j$. 
of some other industry. ${ }^{6}$ Finally, any years chosen as the basis for comparison are likely to have some peculiar characteristics that could affect the conclusions of the analysis. Accordingly, whenever possible, comparisons are reported for a number of different periods.

Table 1 shows estimates of value added and employment due to trade and domestic use in U.S. manufacturing for 1970, 1972, 1973, and $1980 .^{7}$ One can compare 1980 and 1970, years with similar levels of capacity utilization in manufacturing. In 1970, value added related to manufacturing exports was 8.5 percent of overall value added in manufacturing, while the production of manufactured imports at home would have raised value added in manufacturing by 8.3 percent. By 1980 these shares had grown considerably-to 15.1 for exports and 14.4 for imports. ${ }^{8}$ Thus for the period from 1970 to 1980 the trade balance raised value added in manufacturing (in 1972 dollars) by half a percentage point. Although net value added due to trade was $\$ 0.6$ billion in 1970 , it amounted to $\$ 2.6$ billion in 1980 (both measured in 1972 dollars). The positive contributions of trade for 1972-80 and 1973-80 are even larger.

Because products making up U.S. manufacturing imports have lower output per worker when produced in the United States than products making up U.S. exports, net jobs relating to trade were negative in each year in table 1 . However, though there was a decline of 10,000 jobs due

6. For discussions of the methodological issues associated with exercises such as this see Walter S. Salant, The Effects of Increases in Imports on Domestic Employment: A Clarification of Concepts, Special Report 18 (Washington, D.C.: National Commission for Manpower Policy, 1978); and Charles S. Pearson, "Trade Employment and Adjustment," (Ottawa: Institute for Research on Public Policy, forthcoming).

7. There have been a number of studies similar to this with somewhat different emphases. Krueger estimates, for example, that between 1970 and 1976 the average twodigit industry experienced an annual decline in job opportunities resulting from increased imports of about 0.37 percent. See Anne O. Krueger, "Protectionist Pressures, Imports, and Employment in the United States," Working Paper 461 (National Bureau of Economic Research, 1980), p. 20.

Baldwin has decomposed employment by industry into two parts: an effect attributable to income elasticities at home and abroad, and a second competitiveness effect, attributable to changes in relative prices and other factors. See Robert E. Baldwin and others, "U.S. Policies in Response to Growing International Trade Competitiveness, Final Phase I Report" (University of Wisconsin, Center for Research on U.S. Trade Competitiveness, 1982), appendix A.

8. The 15.1 percent for exports is somewhat higher than the estimate of 13.7 percent for employment directly and indirectly related to exports published by the Census Bureau. See U.S. Bureau of the Census, 1980 Annual Survey of Manufactures: Origin of Manufactured Exports, M80 (AS)-6 (January 1982). 
Table 1. Value Added and Employment in U.S. Manufacturing Due to Foreign Trade and Domestic Use, Selected Years, 1970-80

\begin{tabular}{lrrrr}
\hline \multicolumn{1}{c}{ Item } & 1970 & 1972 & 1973 & 1980 \\
\hline Value added (billions of 1972 dollars) & & & & \\
$\quad$ Total & 262.7 & 295.3 & 318.9 & 349.5 \\
$\quad$ Foreign trade & 0.6 & -5.3 & -3.3 & 2.6 \\
$\quad$ Exports & 22.4 & 24.0 & 30.1 & 52.9 \\
$\quad$ Imports & 21.8 & -29.3 & -33.4 & -50.4 \\
$\quad$ Domestic use & & 300.7 & 322.2 & 347.0 \\
Employment (millions) & 19.34 & 19.10 & 20.11 & 20.24 \\
$\quad$ Total & -0.05 & -0.45 & -0.34 & -0.06 \\
$\quad$ Foreign trade & 1.57 & 1.45 & 1.78 & 2.93 \\
$\quad$ Exports & -1.62 & -1.91 & -2.12 & -2.98 \\
$\quad$ Imports & 19.38 & 19.56 & 20.45 & 20.30 \\
$\quad$ Domestic use & & & & \\
Addenda & & & & \\
Percentage due to exports & 8.5 & 8.1 & 9.4 & 15.1 \\
$\quad$ Value added & 8.1 & 7.6 & 8.8 & 14.5 \\
$\quad$ Employment & & & & \\
Percentage due to imports & -8.3 & -9.9 & -10.5 & -14.4 \\
$\quad$ Value added & -8.4 & -10.0 & -10.5 & -14.7 \\
$\quad$ Employment &
\end{tabular}

Sources: Author's calculations using data from U.S. Department of Commerce, Bureau of Economic Analysis, input-output tape; Bureau of Industrial Economics, data base for manufacturing output, exports, and imports; and U.S. Department of Labor, Bureau of Labor Statistics, employment and earnings tape.

a. Estimates of direct and indirect requirements based on the input-output table were used to calculate the proportion of value added related to manufactured exports and to manufactured goods displaced by imports. Value added related to domestic use was calculated as a residual and employment allocated to foreign trade and domestic use in proportion to value added in each two-digit $1-O$ industry.

to trade between 1970 and 1980 , trade raised the number of jobs in U.S. manufacturing by 390,000 from 1972 to 1980 , and by 280,000 from 1973 to 1980 . These increases can be compared with the corresponding total rise in employment in manufacturing of 1.14 million (1972-80) and 130,000 (1973-80), respectively.

It is certainly hard to reconcile these findings with the widespread notion that foreign trade had a major negative effect upon U.S. industrial employment in the 1970s. This perception can be explained in part by the inappropriate use of statistics and in part by the disproportionate attention commanded by a few large industries, especially steel and automobiles. Those seeking to denigrate U.S. manufacturing prowess generally point to the declining U.S. share in global manufactured goods exports. Indeed, from 1970 to 1980 the U.S. share of the value of 
manufactured exports from developed market economies declined from 17.4 percent to 15.4 percent. This measure is obviously inappropriate, however, for the purposes of this analysis. For employment the data on U.S. manufactured trade volumes are more germane: the volume of U.S. manufactured exports increased by 101.5 percent from 1970 to 1980 , whereas manufactured imports increased only 72.0 percent. ${ }^{9}$

Several real devaluations of the dollar in the 1970s were important in determining these trade flows. Empirical evidence linking trade flows to relative price changes has caused some controversy. Those claiming to find no relation between the two generally seek a contemporaneous response. ${ }^{10}$ Statistical studies that look for lags over periods of at least three years find sizable effects. ${ }^{11}$ Thus, claims to the contrary notwithstanding, the U.S. performance reflects the sensitivity of trade flows to changes in relative prices. Between 1970 and 1980 there was a marked improvement in U.S. relative price competitiveness that took the form of a real depreciation of the U.S. dollar. The real increase in the

9. United Nations, Monthly Bulletin of Statistics, vol. 36 (December 1982), pp. xxiv$\mathrm{xxv}$. By contrast, the increase in volumes of manufactured exports in Japan, Germany, and all developed countries from 1970 to 1980 was $155.7,71.0$, and 90.3 percent, respectively.

10. In a prominent study published by GATT (General Agreement on Tariffs and Trade), Blackhurst and Tumlir argue that real exchange rates have not had the predicted effects on trade balances. They conclude: "In general, only by invoking long lags-often of two years or more-between exchange rate change and the initial impact on the trade balance would it be possible to salvage even partially the conventional view.' See Richard Blackhurst and Jan Tumlir, "Trade Relations under Flexible Exchange Rates," GATT Studies in International Trade, 8 (Geneva: General Agreement on Tariffs and Trade, 1980), p. 27.

11. $₫ \rightarrow$ Michael C. Deppler and Duncan M. Ripley, "The World Trade Model: Merchandise Trade," IMF Staff Papers, vol. 25 (March 1978), pp. 147-206; Rudiger Dornbusch and Paul Krugman, "Flexible Exchange Rates in the Short Run," BPEA, 3: 1976, pp. 537-75; Helen B. Junz and Rudolf R. Rhomberg, "Price Competitiveness in Export Trade among Industrial Countries," American Economic Review, vol. 63 (May 1973, Papers and Proceedings, 1972), pp. 412-18; Stephen P. Magee, "Prices, Incomes, and Foreign Trade," in Peter B. Kenen, ed., International Trade and Finance: Frontiers for Research (Cambridge University Press, 1975), pp. 175-2 $\rightarrow$ Mordechai E. Kreinin, "The Effect of Exchange Rate Changes on the Prices and Volume of Foreign Trade," IMF Staff Papers, vol. 24 (July 1977), pp. 297-329; Irving B. Kravis, Robert E. Lipsey, and Dennis M. Bushe, "Prices and Market Share in International Machinery Trade," Working Paper 521 (National Bureau of Economic Research, 1980); and Raymond Fair, "Estimated Effects of Relative Prices on Trade Shares," Working Paper 696 (National Bureau of Economic Research, 1981). 
manufacturing trade balance can be ascribed, in part, to the effects of the dollar devaluations in 1971, 1973, and 1978-79. ${ }^{12}$

\section{A Disaggregated Analysis}

Although much of the discussion about U.S. deindustrialization has been about manufacturing as a whole, the discussion in fact corresponds to developments in just a few industries. Tables A-1 and A-2 in the appendix present disaggregated data on value added and employment to illustrate this. Some results in those tables may appear paradoxical. In particular, if employment due to trade in an industry is initially negative, indicating that imports, on balance, are displacing more jobs than exports are creating, then a labor-saving change in value added or productivity will expand employment due to trade by bringing it nearer to zero. ${ }^{13}$

The employment shifts reported in table A-2 for 1970-80 reveal several features. First, in a majority (thirty-one of the fifty-two) of the U.S. industrial sectors employment growth was positive; employment due to trade also grew in thirty-one I-O sectors. Second, generally the effects of trade on employment were smaller than those due to domestic use: in forty-two of the fifty-two sectors the change due to trade was smaller in absolute magnitude than the change due to domestic use. Third, trade was not the reason for the drop in employment in most of the declining industries. In six of the nine industries in which employment fell more than 10 percent employment due to trade actually increased; only in footwear and apparel was the loss due to trade greater than that due to domestic use. Similarly, employment due to trade increased in fourteen of the twenty-one industries in which overall employment fell: only in three industries-radio and television, motor vehicles, and miscellaneous manufacturing - was a decline due to trade larger than an increase due to domestic use.

From 1973 to 1980 the positive influence of trade was even more widespread-employment due to trade rose in thirty-eight of the fifty-

12. Price sensitivity is the major source of the decline in the U.S. manufacturing trade balance from 1980 to 1982 .

13. Because of productivity changes, the changes in value added in any sector may be in the reverse direction from the corresponding changes in employment. If value added per employee rises by $x$ percent, value added must rise by $x$ percent simply to keep employment unchanged. 
two sectors considered. However, overall employment declined in twenty-five of the sectors, primarily because of domestic use. In none of the industries in which total employment declined was a positive effect due to domestic use offset by a negative effect due to trade. Although trade contributed to the employment loss in seven of the twenty-five sectors, the decline due to trade was larger than the decline due to domestic use in only footwear and miscellaneous manufacturing.

For the decade as a whole, an interval over which cyclical variations in demand were unimportant, the automobile industry is virtually the only industry whose experience fits the widely held view that employment declines were due to trade and that without trade, employment would have grown. Even in automobiles, as the International Trade Commission confirms, the major sources of the industry's problems are domestic. As reported in table A-1, of the 24.1 percent decline in the output of the U.S. automobile industry from 1973 to 1980 , 18.6 percent could be attributed to a decline in domestic use and 5.5 percent to changes in the net trade balance. Even if Japanese imports had remained constant during this period, the problems faced by the U.S. automobile industry and its suppliers would have been severe. A relative rise in wages in the automobile industry and the impact of regulation have raised relative prices of U.S. automobiles. ${ }^{14}$ Furthermore, the increase of gasoline prices, fears of gas shortages-and, after 1979, high real interest rates and depressed cyclical conditions-have further suppressed the demand for cars.

The role of domestic use in reducing demand is even greater in the steel industry than in automobiles. The domestic use of iron and steel lowered output from 1970 to 1980 by 2.7 percent; from 1973 to 1980 , by 23.0 percent. Clearly even if foreign trade had not reduced domestic steel output by a total of 3.4 percent between 1970 and 1980 , these would have been difficult times for the U.S. steel industry. From 1973 to 1980 net foreign trade partially offset-by 0.5 percent-the decline in U.S. output due to domestic use. ${ }^{15}$

14. Had imported automobiles retained their 1980 share in the U.S. automobile market in the first half of 1982 , for example, only a fifth of the U.S. automobile workers unemployed since 1980 would have retained their jobs.

15. My measures of the effect due to trade include the indirect effects of trade in other products besides steel. Thus an important source of the output gains from trade for steel is the rise in U.S. exports of machinery. 
Despite smaller changes due to trade than those due to domestic use, public perceptions may be exaggerating the role of trade because the effects of trade and domestic use have been positively correlated. For reasons unrelated to international trade, the U.S. manufacturing sector has been undergoing major structural shifts in output and employment because of domestic demand and technology. The impact of trade has in some cases reinforced these domestic changes; in other cases, industries experiencing employment losses because of domestic use have had only minor offsets as a result of trade. This correspondence between trade and domestic use is apparent at the relatively disaggregated level of the fifty-two I-O industries. From 1973 to 1980, for example, there was a 0.49 correlation between the contributions to value added of domestic use and those of foreign trade.

The correspondence between growth related to domestic use and growth related to trade can be seen clearly when the fifty-two industries are aggregated according to the nature of the production process. In the trade literature it is customary to group goods into three groups: goods that require the relatively intensive use of natural resources (termed Ricardo goods), goods that require high proportions of research and development or employ scientists and engineers fairly intensively (product-cycle or high-technology goods), and goods that use relatively standardized production technologies (Hecksher-Ohlin goods). In this paper I adopt the Ricardo (resource-intensive) and product-cycle (hightechnology) groupings and divide the Hecksher-Ohlin group according to relative capital-labor ratios into capital- and labor-intensive categories. ${ }^{16}$

The data in table 2 highlight the change in the composition of U.S. output and employment in manufacturing. They indicate the long-run shift toward high-technology sectors in both output and employment. The employment shift proceeded at about the same pace between 1970 and 1980 as during the previous decade, although the shift measured by value added accelerated somewhat. But from 1973 to 1980 the shift

16. The ratio of employment to gross capital stock in 1976 at the three-digit SIC level was used to divide the Hecksher-Ohlin group. The detailed classification scheme used by Stern and Maskus has been matched with the fifty-two I-O categories as indicated in table A-3 of the appendix. See Robert M. Stern and Keith E. Maskus, "Determinants of the Structure of U.S. Foreign Trade, 1958-76,' Journal of International Economics, vol. 11 (May 1981), pp. 207-24. 
Table 2. Shares of Value Added and Employment in U.S. Manufacturing, by Production Characteristics of Industries, Selected Years, 1960-80

Percent

\begin{tabular}{lccccc}
\hline \multicolumn{1}{c}{ Item } & 1960 & 1970 & 1972 & 1973 & 1980 \\
\hline Value added $^{\mathrm{a}}$ & & & & & \\
High-technology & 27 & 31 & 31 & 32 & 38 \\
Capital-intensive & 32 & 30 & 31 & 32 & 27 \\
Labor-intensive & 13 & 13 & 14 & 13 & 12 \\
Resource-intensive & 28 & 25 & 24 & 23 & 23 \\
Employment $^{\text {b }}$ & & & & & \\
High-technology & 27 & 30 & 28 & 29 & 33 \\
Capital-intensive & 29 & 29 & 30 & 30 & 28 \\
Labor-intensive & 21 & 20 & 21 & 21 & 19 \\
Resource-intensive & 23 & 21 & 21 & 20 & 20 \\
\hline
\end{tabular}

Sources: Same as table 1.

a. Value added computed for each input-output (I-O) industry by multiplying gross output in 1972 dollars by the ratio of value added to output in the $1972 \mathrm{I}-\mathrm{O}$ table.

b. Employment is derived from the Bureau of Labor Statistics series on employment and earnings. The series have been aggregated to the two-digit I-O industry and then to the process categories.

toward high technology accelerated by both measures. In the thirteen years from 1960 to 1973 , the share of high-technology products in total value added increased from 27 to 32 percent. In the next seven years it rose from 32 to 38 percent. The acceleration in employment share in high-technology sectors is even more dramatic; after increasing from 27 percent in 1960 to 29 percent in 1973, it rose to 33 percent by 1980 .

Table 3 breaks down the striking divergence of the high-technology sector from the rest of manufacturing into the parts accounted for by domestic use and foreign trade. Between 1973 and 1980, output of hightechnology products increased by 30.6 percent and employment rose by 15.7 percent; in industries characterized by other production processes, output grew sluggishly and employment declined. The compositional changes were related to growth resulting from both trade and domestic use. Although most of the employment growth in the high-technology sector can be ascribed to the rise in domestic use, growth in employment from foreign trade was greater in this sector than in any other. Foreign trade also raised employment in resource-intensive industries, where domestic demand was sluggish. Stagnant or falling domestic demand, combined with a reinforcing decline in net foreign demand, thwarted growth in both capital- and labor-intensive industries. In the following sections I turn to more detailed explanations for the behavior of the composition of domestic use and foreign trade. 
Table 3. Percentage Change in Value Added and Employment in U.S. Manufacturing Due to Foreign Trade and Domestic Use, by Production Characteristics of Industries, 1970-80 and 1973-80

\begin{tabular}{lrrrrrrr}
\hline & \multicolumn{3}{c}{$1970-80$} & & \multicolumn{3}{c}{$1973-80$} \\
\cline { 8 - 8 } \multicolumn{1}{c}{ Item } & \multicolumn{3}{c}{$\begin{array}{c}\text { Domestic } \\
\text { use }\end{array}$} & $\begin{array}{c}\text { Foreign } \\
\text { trade }\end{array}$ & Total & $\begin{array}{c}\text { Domestic } \\
\text { use }\end{array}$ & $\begin{array}{c}\text { Foreign } \\
\text { trade }\end{array}$ \\
\hline Value added & & & & & & \\
Total & 33.1 & 32.3 & 0.8 & 9.6 & 7.8 & 1.9 \\
High-technology & 61.9 & 54.7 & 7.2 & 30.6 & 25.2 & 5.4 \\
Capital-intensive & 18.4 & 22.2 & -3.8 & -7.3 & -6.7 & -0.6 \\
Labor-intensive & 16.5 & 20.7 & -4.1 & -2.1 & -0.2 & -1.9 \\
Resource-intensive & 23.4 & 22.6 & 0.8 & 10.7 & 8.2 & 2.5 \\
Employment & & & & & & \\
Total & 4.7 & 4.7 & 0.0 & 0.7 & -0.7 & 1.4 \\
High-technology & 16.4 & 12.9 & 3.5 & 15.7 & 11.1 & 4.6 \\
Capital-intensive & 0.3 & 2.3 & -1.9 & -6.0 & -5.9 & -0.1 \\
Labor-intensive & -1.8 & 1.8 & -3.6 & -8.2 & -6.3 & -2.0 \\
Resource-intensive & 0.5 & -0.6 & 1.1 & -1.5 & -4.1 & 2.6 \\
\hline
\end{tabular}

Sources: Same as table 1.

a. See notes to tables 1 and 2 .

\section{Patterns of Domestic Use: High Technology and Demand}

Looking at the detailed data on industries and the product aggregation, one is struck by the degree to which most of the story of structural change can be told simply by looking at the data on domestic use.

Output due to domestic use was weakest in old U.S. industries such as tobacco, wood containers, leather goods, iron and steel, and metal containers. The sectors with the highest increases in domestic use were all high-technology sectors. From 1970 to 1980 several of these industries had increased output due to greater domestic use: for example, output in office, computing, and accounting machines increased 253 percent; electronic components, 219 percent; optical equipment, 123 percent; and plastics, 90 percent. Of the high-technology industries, only aircraft had a negative effect due to domestic use. Thus the patterns associated with the performance of U.S. industrial growth in the 1970s are all present in the data on domestic use: considerably more rapid output gains in high-technology and equipment industries, relatively slower growth in all major process and end-use categories in the 1970s, particularly sluggish performance in U.S. labor- and capital-intensive industries, and weak growth of industries such as leather, wood containers, 
tobacco products, and metal products. Almost all these developments have been reinforced by the impact of foreign competition, although their directions and general magnitudes would be the same without the effects due to foreign trade.

Explanations of the accelerated shift toward high-technology production since 1972 often cite the influence of foreign trade or a speedup in the pace of technological change. But neither of these explanations seems sufficient. As shown in table 3, the accelerated shift is present even when the effects of trade are excluded. Thus trade is certainly not all of the story. As for faster technological change, table 4 shows that employment, output, and productivity (output per employee) in hightechnology industries grew more slowly from 1973 to 1980 than they did in the 1960s. In fact, as measured by the growth in output per employee, the slowdown in productivity growth in the high-technology industries has been quite similar to the productivity slump elsewhere in manufacturing. This makes it doubtful that faster technological change is the explanation.

What other explanations might account for the relatively strong output gains in high-technology products during 1973-80? One might be the relatively high income-elasticity of demand for these products and the low income-elasticity of demand for older commodities. Wealthy consumers devote declining shares of their incomes to basic needs such as clothing, footwear, furniture, and simple electrical appliances. Conversely, they increase the share devoted to computers, aircraft, and communications equipment. Thus, with the expansion of income, basic commodities can be expected to have declining shares. But if income elasticities have the dominant effect, the share of high-technology industries increases more rapidly in periods of high rather than low income growth. ${ }^{17}$

Perhaps, however, it is precisely because income effects were so small during the 1973-80 period that the share of high-technology products has grown. In explaining the demand for a product, it is customary to distinguish between income and substitution effects. In the absence of price declines, because their qualitative nature changes very little, the market for standardized commodities will only expand in

17. If, for example, income growth rates were infinite, commodities with elasticities of less than 1.0 would tend to have zero shares; if growth were zero, shares would remain constant. Thus the more rapid is the growth rate, the faster the shares of products with high income-elasticities expand. 
Table 4. Growth of Employment, Value Added, and Productivity in U.S. Manufacturing, High- and Low-Technology Goods, Selected Periods, 1960-82

Average annual growth rates, in percent

\begin{tabular}{lcccc}
\hline \multicolumn{1}{c}{ Item } & $1960-70$ & $1970-80$ & $1973-80$ & $1980-82$ \\
\hline Employment & & & & \\
High-technology & 2.5 & 1.5 & 2.1 & -2.4 \\
$\begin{array}{l}\text { Low-technology } \\
\text { Value added }\end{array}$ & 1.0 & 0.0 & -0.8 & -4.2 \\
High-technology & 5.7 & 4.9 & 3.9 & n.a. \\
Low-technology & 3.2 & 1.8 & 0.0 & n.a. \\
$\begin{array}{l}\text { Productivity } \\
\text { High-technology }\end{array}$ & 3.1 & 3.4 & 1.7 & n.a. \\
Low-technology & 2.2 & 1.9 & 0.8 & n.a. \\
\hline
\end{tabular}

Sources: Same as table 1.

n.a. Not available.

a. In 1972 dollars.

b. Value added divided by employment.

the face of income growth. Thus under depressed cyclical conditions the demand for the products of U.S. industries such as textiles, iron, steel, other basic metals, fabricated metals, and automobiles will be particularly sluggish. Income growth is likely to be less important as a determinant of the demand for a new product. It might be possible to increase sales of Sony Walkman radio-earphone sets in the midst of a recession, for example, whereas it is not possible to raise the sales of portable radios. Substitution effects due to price and quality changes are likely to dominate income effects.

With the correct hedonic measures, all quality changes theoretically can be appropriately recorded as relative price changes. In reality, however, such adjustments are not made, so it is reasonable to decompose substitution effects into those due to price changes and those due to quality changes. If the relatively more rapid productivity growth in high-technology products resulted in relatively lower prices, and if demand were elastic, this could account for the growth in employment. My use of the deflators at the four-digit SIC level to estimate the relative value-added changes of the end-use categories failed to confirm this hypothesis. When compared with the overall rise in value added for manufactured goods, the natural resource industries had increases of 49 percent in relative unit value added from 1972 to 1980 , but both capital-intensive and high-technology products declined about 9 percent each and labor-intensive products, 15 percent. Thus one is left with the hypothesis that changes of a qualitative nature not captured by conven- 
tional measurement practices account for the resilience in demand for high technology. ${ }^{18}$ A second source of substitution effects during this period could of course be the demand for more energy-efficient products. The close correspondence between the high-technology and equipment groupings suggests this possibility (see table A-3).

\section{The Role of U.S. Trade}

The Hecksher-Ohlin theory of trade predicts that an economy will specialize in the production of commodities requiring the relatively intensive application of its more abundant factors of production. Empirical applications of the theory have been moderately successful in explaining the composition of U.S. trade at particular points in time. U.S. trade surpluses are in commodities made with relatively abundant factors of production-land (food) and skilled and highly educated labor (chemicals, capital goods, and services); U.S. trade deficits are in commodities made with unskilled labor (nondurable consumer goods) or requiring resources that have been depleted (fuels). It is more difficult to identify the contribution of physical capital in calculating U.S. comparative advantage. ${ }^{19}$ As Branson has observed, "Physical capital plays a more neutral role, combining relatively more with human capital in exports and unskilled labor [and natural resources] in imports. Good examples may be chemicals on the export side and consumer electronics [and steel] on the import side." 20

The theory also helps explain changes in U.S. specialization patterns

18. This argument is compatible with Martin Neil Baily's point that events since 1973 have led to the premature retirement of capital. See "Productivity and the Services of Capital and Labor,' BPEA, 1: 1981, pp. 1-67.

19. The debate about the role of capital goes back as far as Leontief's famous 1953 article, which found the United States exporting goods embodying labor and importing goods embodying capital. See Wassily W. Leontief, "Domestic Production and Foreign Trade: The American Capital Position Reexamined," Proceedings of the American Philosophical Society, vol. 97 (Philadelphia: 1953), pp. 332-49. Surveys of subsequent efforts to explain Leontief's findings are found in James C. Hartigan, "The United States Tariff and Comparative Advantage, A Survey of Method," Weltwirtschaftliches Archiv, vol. 117, no. 1 (1981), pp. 65-109. See also Robert M. Stern, "Testing Trade Theories," in Kenen, International Trade and Finance, pp. 3-50.

20. See William H. Branson, "Trends in U.S. International Trade and Investment since World War II," in Martin Feldstein, ed., The American Economy in Transition (University of Chicago Press, 1980), p. 236. For a comprehensive survey of general studies on this subject see Stern, "Testing Trade Theories." 
over time. As foreign economies have grown more rapidly than the U.S. economy and as they generally have had higher ratios of investment to GNP, the U.S. share of the global capital stock has declined markedly. However, the U.S. share of skilled labor has decreased relatively little, and its share of global arable land has actually increased. ${ }^{21}$ These changes in relative factor endowments are therefore consistent with the increased U.S. specialization in products that are intensive in skilled labor and land and the decreased specialization in capital-intensive products. ${ }^{22}$

A less formal but more dynamic explanation of the pattern of U.S. trade incorporates the role of changes in technological and production capabilities and the growth of economies of scale that accompanied the convergence of foreign nations toward U.S. productivity levels. In the early 1950s the United States dominated global manufacturing capacity. In 1950 the United States produced about 60 percent of the manufactured goods output in the Western industrial countries, and in 1953 it accounted for about 29 percent of the world exports of manufactured goods. In almost every field U.S. firms stood at the technological frontier and enjoyed the economies of scale resulting from access to a large, integrated, and extremely wealthy market. American inventors designed products primarily with a view toward saving labor, and as foreign productivity levels increased and real wages rose these products became increasingly attractive abroad. World War II stimulated technological advances in computers, aircraft, and pharmaceuticals, and although it severely crippled civilian production facilities abroad, in the United States the capital stock remained intact.

The shortage of foreign manufacturing capacity can be inferred from the surpluses in the U.S. balance of trade in all major end-use categories in 1950, including those in which the United States had deficits before the war. ${ }^{23}$ Industrialization abroad boosted the U.S. balance of trade in

21. Bowen has calculated that the U.S. share of global supplies of capital has declined (from 42 percent in 1963 to 33 percent in 1975), while the share of skilled labor declined by much less (from 29 to 26 percent), and its world share of arable land actually increased (from 27 to 29 percent). See Harry P. Bowen, "Shifts in the International Distribution of Resources and the Impact of U.S. Comparative Advantage," forthcoming in Review of Economics and Statistics.

22. Stern and Maskus report that in a series of annual regressions explaining trade the coefficient on unskilled labor becomes increasingly statistically significant over time and the coefficient on capital, increasingly negative. See Stern and Maskus, "Determinants of the Structure of U.S. Foreign Trade, 1958-76."

23. See William H. Branson and Helen B. Junz, "Trends in U.S. Trade and Comparative Advantage,' BPEA, 2: 1971, pp. 285-338. 
capital goods and chemicals, but by the late 1950s the rebuilding of Europe and the expansion of Japanese exports of textiles eroded the trade surpluses in semimanufactured goods and consumer products. In the mid-1960s foreign steel and automobiles were penetrating the U.S. market in substantial quantities, and the trade balances in semimanufactured products and automobiles became negative. As U.S. imports from the developed nations moved up the technology spectrum, the developing nations began to enter the market and make up increasing shares of U.S. imports of standardized labor-intensive consumer products.

On the one hand, the range of U.S. imports broadened to mirror the different stages of development of its trading partners-with laborintensive imports originating in developing nations and capital-intensive and high-technology products originating in the industrial economies. On the other hand, the range of U.S. exports narrowed, and it became increasingly confined to capital goods, chemical and agricultural products, and services.

In the 1970s this process of U.S. specialization continued. The trade between developing nations and the United States evolved along the lines of comparative advantage associated with factor endowments related to different stages of development. However, production and technological capabilities of foreign industrial countries converged toward those of the United States, and those countries now compete with U.S. firms in high-technology products. ${ }^{24}$ The U.S. market no longer provides American firms with unique opportunities for realizing economies of scale. ${ }^{25}$ Indeed, foreign innovations that were directed primarily toward saving raw materials (small automobiles, for example) have become increasingly attractive to American consumers. ${ }^{26}$

24. For a detailed analysis of U.S. trade in high-technology products see C. Michael Aho and Howard F. Rosen, "Trends in Technology-Intensive Trade," Economic Discussion Paper 11 (Office of Foreign Economic Research, U.S. Department of Labor, 1980); Jack Baranson and Harald B. Malmgren, "Technology and Trade Policy: Issues and an Agenda for Action," paper prepared for the Bureau of International Affairs, Department of Labor, and the Office of the U.S. Trade Representative (Washington, D.C.: 1981); and Sumiye Okubo, "The Impact of Technology Transfer on the Competitiveness of U.S. Producers," in Report of the President on U.S. Competitiveness (Office of Foreign Economic Research, U.S. Department of Labor, September 1980).

25. This is confirmed in C. Michael Aho and Richard D. Carney, "An Empirical Analysis of the Structure of U.S. Manufacturing Trade 1964-1976,' Economic Discussion Paper 3 (Bureau of International Labor Affairs, Department of Labor, June 1979).

26. See Raymond Vernon, "Gone Are the Cash Cows of Yesterday," Harvard Business Review, vol. 58 (November-December 1980), pp. 150-55. 
The literature disputes the precise sources of the U.S. advantage in high-technology manufactured goods. Does it result from the relative abundance of engineers and scientists, the relatively large amounts spent on $R \& D$, or the market inducements to innovate in a rich economy? The strong interactions among these factors inhibit quantification of the contribution of each. ${ }^{27}$ However, it is possible to provide a snapshot of the kinds of manufactured goods the United States succeeds in exporting and those in which import penetration has been the greatest.

U.S. export industries have made large investments in R\&D and are at the technological frontier. ${ }^{28}$ The products are often novel, require specialized production methods, and benefit during their development from being close to the market in which they are sold. Staying ahead requires continual innovation to offset the inevitable standardization of the production process and the international diffusion of technology. Conversely, U.S. imports, especially those from developing countries, are by and large mature and standardized products that can be massproduced using skills that can be quickly acquired. They may be manufactured products requiring unskilled labor (such as apparel and footwear) or products requiring capital relatively intensively (such as steel).

The growing importance of high-technology trade to the United States is illustrated by figure 1, which contrasts the U.S. trade balances in R\&D- and non-R\&D-intensive products. ${ }^{29}$ The geographic distribution of the U.S. trade balances in R\&D-intensive products corresponds to the relative stages of development of U.S. trading partners.

In summary, therefore, the impact of trade has not been to shrink the U.S. manufacturing sector, and the United States has not lost its comparative advantage in manufacturing as a whole. The United States has been developing a comparative advantage in high-technology (and resource-intensive) products, while its comparative advantage in labor-

27. On this question, see Thomas C. Lowinger, "The Technology Factor and the Export Performance of U.S. Manufacturing Industries," Economic Inquiry, vol. 3 (June 1975), pp. 221-36.

28. The classic generalization along these lines is Vernon's product-cycle theory. See Raymond Vernon, "International Investment and International Trade in the Product Cycle," Quarterly Journal of Economics, vol. 80 (May 1966), pp. 190-207.

29. The United States has maintained its share in world trade of high-technology products far better than in more routine goods. See Bela Balassa, "U.S. Export Performance: A Trade Share Analysis," Working Papers in Economics, 24 (Johns Hopkins University, 1978). 
Figure 1. U.S. Trade Balance in R\&D-intensive and Non-R\&D-intensive Manufacturing, 1960-79a

Billions of dollars

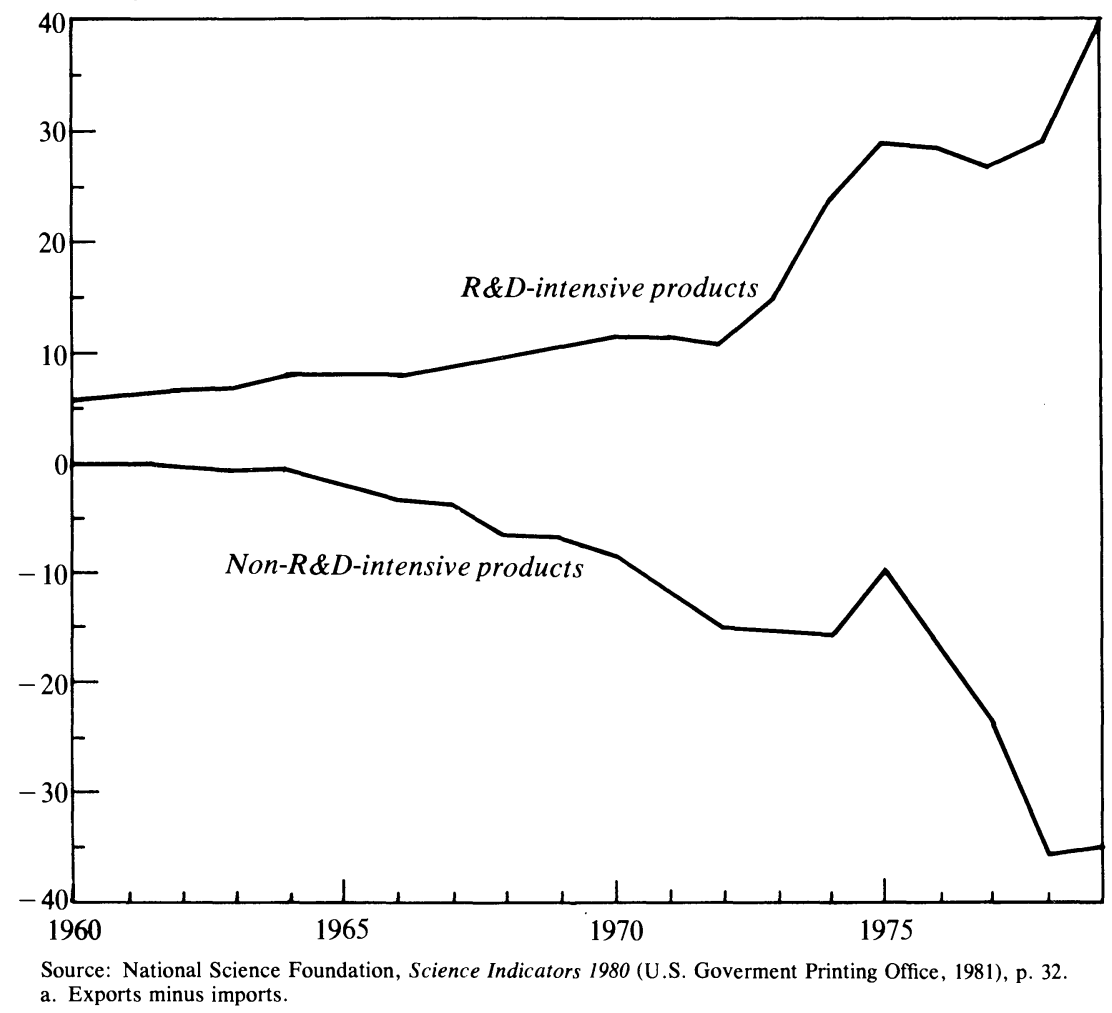

intensive and capital-intensive products manufactured with standardized technologies has been eroding. There is, therefore, a correspondence between the U.S. industries experiencing slow economic growth because of sluggish domestic use and those experiencing declining comparative advantage.

The direction of structural change in U.S. domestic markets and in U.S. comparative advantage may well be causally linked. The shift toward the demand for high-technology products domestically may be an important source of the growth in comparative advantage of the United States in these products; and conversely, the shifts away from older products may have contributed to their relative decline. Burenstam Linder stresses the availability of markets and associated scale-econ- 
omies rather than of factors of production such as capital or labor as the major determinant of comparative advantage and suggests that countries export goods that are demanded in their home markets. ${ }^{30}$

\section{Structural Adjustment}

Employment shifts required by structural change generally can be easily accomplished by the U.S. economy. If the changes that occurred in 1970-80 indicate the magnitude of long-run structural shifts, for most declining industries the annual average employment drop is rather small. Taken together, employment in low-technology industries fell by 0.3 percent over the decade-an average of 0.03 percent a year, while the decline from the cyclical peak in 1973 through the more slack conditions in 1980 averaged 0.82 percent a year. In fact, the employment loss due to structural change over the entire decade of the 1970s was considerably smaller than the drop in one year of a major recession. For example, from 1973 to 1975 , employment in low-technology sectors fell at an annual average rate of 5.3 percent, while from 1979 to 1982 the drop averaged 4.3 percent a year.

To be sure, in some industries the pace of decline during the decade was somewhat more rapid. In the wood containers and leather products industries-the sectors with the greatest employment loss from 1970 to 1980 - the declines averaged 3.3 and 2.4 percent a year, respectively. Yet considering the typical rate at which workers voluntarily quit their jobs, even these industries would have been able to cope with a smooth declining employment trend without involuntary layoffs. The problem is that such changes do not occur smoothly; they coincide with the business cycle and may take the form of lumpy plant closures rather than smooth exponential decay.

\section{Recent Experience}

Much of the current concern about trade in manufactured products in particular and structural change in general stem not from the trends of the 1970s, but from the much sharper effects on manufacturing industries 1961).

30. Staffan Burenstam Linder, An Essay on Trade and Transformation (John Wiley, 
that came from the strong dollar and the 1980-82 recession. An intensive investigation of the relative role of trade in manufacturing and other factors during this period is beyond the scope of this paper and, in any case, the data to undertake such an analysis are not yet at hand. Nonetheless, some observations can be made about the role of trade and structural change in the recent developments in manufacturing.

A substantial proportion of the decline in U.S. manufacturing employment from 1980 to 1982 was due to changes in trade flows, particularly exports. Between these two years, the volume of U.S. manufactured goods exports declined 17.5 percent. The volume of manufactured goods imports rose 8.3 percent. As estimated above, employment due to manufactured exports in 1980 was 2.93 million. Since output per employee in manufacturing was similar in 1980 and 1982, employment and output due to trade most likely declined proportionally. ${ }^{31}$ This suggests an employment decline of 513,000 persons, or about 34 percent of the total 1.51 million decline in manufacturing employment from 1980 to 1982, was due to the fall in manufactured exports.

The jobs lost to imports can be estimated on two alternative assumptions. As estimated above, imports were displacing 2.9 million U.S. jobs in 1980. If one assumes rising import volumes added proportionately to this job displacement, the 8.3 percent rise in import volumes between 1980 and 1982 displaced an additional 240,000 U.S. jobs. Alternatively, if the value of U.S. demand is assumed to rise with domestic prices and the value of U.S. production is reduced by an amount equal to the higher value of imports, the estimated job loss is negligible since import values and domestic prices both rose by about 14 percent.

The decline in the U.S. manufacturing trade balance during 1980-82 has a simple explanation: it is primarily the result of the rise in the relative price of U.S. manufactured goods associated with the real appreciation of the U.S. dollar. According to calculations of the International Monetary Fund, during this period U.S. unit values for manufactured exports increased by 31 percent relative to those of major industrial competitors. ${ }^{32}$ Although the global recession and the liquidity and debt problems

31. The declines in manufacturing employment and industrial production from 1980 to 1982 were 7.1 and 6.2 percent, respectively. See Economic Report of the President, February 1983, pp. 205, 210.

32. International Monetary Fund, International Financial Statistics, series 74ey 110. 
of developing countries were contributing factors in retarding U.S. export markets toward the end of the period, the OECD has estimated that the market for U.S. manufactured goods actually increased by about 5.3 percent from 1980 to $1982 .{ }^{33}$

Much has been made of the structural nature of the unemployment in U.S. manufacturing during 1980-82. It is commonly argued that the jobs lost in the current recession in basic industries will not be replaced even if the economy recovers strongly. But with a return of the exchange rate to near its 1980 level and a recovery of the economy, there is no reason to believe this. As I argue above, it is normal in a recession for hightechnology employment to decline less rapidly than employment in the rest of manufacturing. From 1979 to 1982, high-technology employment fell about 3.4 percent a year less rapidly than the rest of manufacturinga differential that was remarkably similar to that in 1973-75. The 1.8 percent differential that occurred in 1980-82 was quite similar to the 1.6 percent differential for the 1970s as a whole.

Regressions of employment in high- and low-technology industries against a time trend and capacity utilization in manufacturing over the 1970s indicate a slight upward long-run trend for low-technology employment of about 0.2 percent a year and an increase of about 1.8 percent a year for high-technology employment. This trend and actual employment are shown in figure 2 . Had capacity utilization been at its 1970-80 average, employment in 1982 in high- and low-technology industries would have been higher by 260,000 and 1.5 million, respectively. A more competitive value of the dollar would have added still more to employment, as already noted.

A return to the long-run employment trend by 1990 would entail average annual employment gains during $1982-90$ of 2.5 and 1.5 percent a year in high- and low-technology manufacturing, respectively. In summary, employment in manufacturing has fallen considerably below its long-run trend. Given reasonable economic expansion and international price competitiveness, structural change should now be relatively easy to accommodate in the remainder of the 1980s.

33. Organization for Economic Cooperation and Development, OECD Economic Outlook (Paris: OECD, December 1982), p. 125. For a more complete analysis of 1980-82 see Robert Z. Lawrence, Can America Compete? (Brookings Institution, forthcoming). 
Figure 2. Employment in High- and Low-Technology Manufacturing, 1968-90a

Employment (millions)

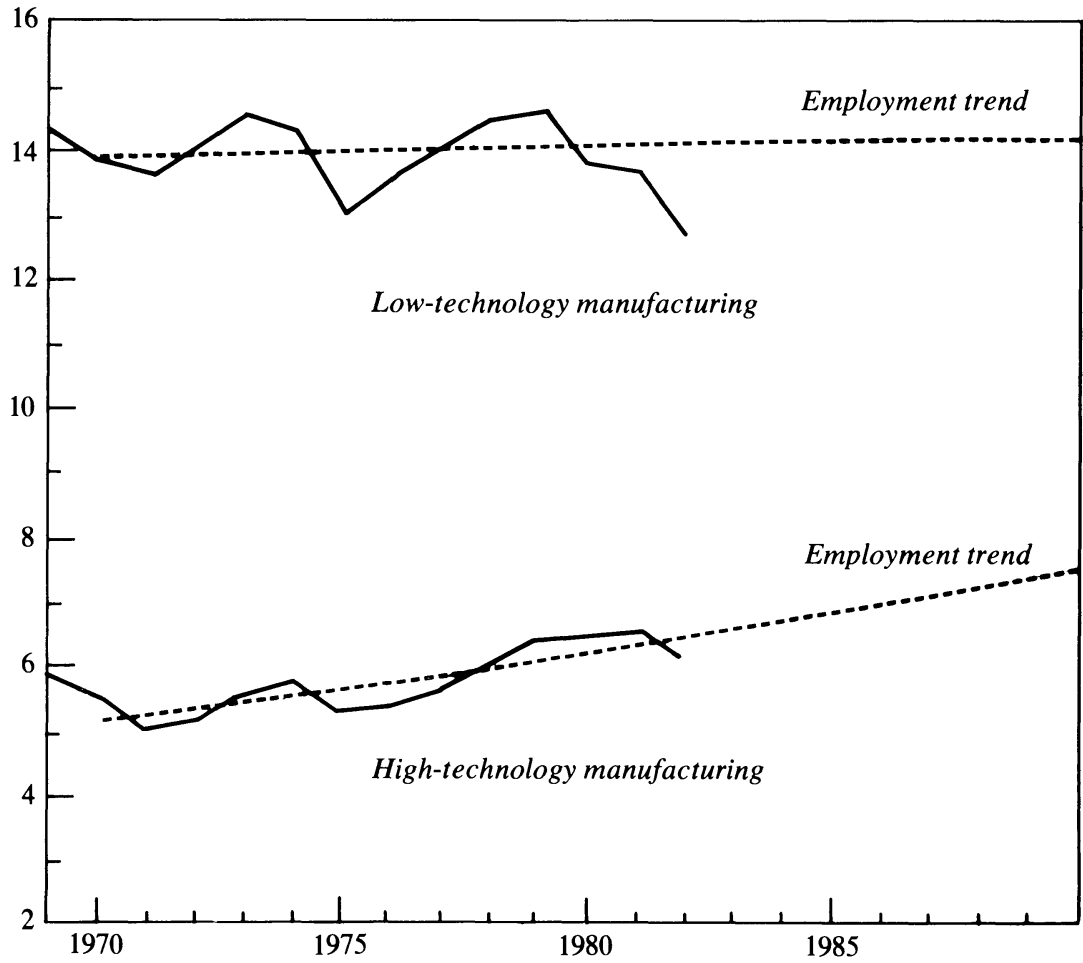

Sources: U.S. Bureau of Labor Statistics, Employment and Earnings, historical data tape; and Board of Governors of the Federal Reserve System, data series on capacity utilization in manufacturing.

a. Industries are divided into high and low technology at their three-digit Standard Industrial Classification level based on the "product-cycle" division in Robert M. Stern and Keith E. Maskus, "Determinants of the Structure of U.S. Foreign Trade: 1958-76," Journal of International Economics, vol. 11 (May 1981), pp. 207-24. I make one addition to high technology: SIC 3761, guided missiles and space vehicles. To estimate employment trends, I first regressed the log of employment against a time trend and capacity utilization in manufacturing for 1970-80. Then, in the resulting equation, I replaced capacity utilization with the average capacity utilization for 1970-80 to derive trend employment for 1970-90.

\section{Employment Growth and High Technology}

Would the current job losers from the low-technology industries be employable in high-technology industry? To some degree, those displaced will find employment in other sectors of the economy. The issue of structural mismatch across manufacturing remains, however. In particular, there has been concern about the distributional effects of 
changes in the structure of U.S. manufacturing trade. ${ }^{34}$ Some major characteristics of workers in high- and low-technology industries are shown in table 5. An examination of the averages reported in the table suggests differences that might be expected: workers in high-technology industries tend to be more highly paid, better educated, male, white, younger, and less unionized than their low-technology counterparts. ${ }^{35}$ The differences in regional location and occupation characteristics between high- and low-technology workers generally are surprisingly small. ${ }^{36}$ This suggests that most of the workers could be employed in either sector.

The common perceptions of the structural adjustment problem are not captured by the aggregate numbers but are again heavily influenced by the characteristics of a few prominent industries. Some striking differences can be seen when one compares characteristics of the steel and automobile industries with those of the computer industry, as reported in table 5 . The greater visibility and political influence of the steel and automobile industries have perhaps exaggerated their importance. First, these are industries traditionally and perhaps anachronistically associated with industrial prowess. Second, automobiles in particular are viewed as an important source of employment and demand in other industries-for example, in 1972, total direct and indirect employment relating to U.S. motor vehicle employment amounted to almost 10 percent of total employment in U.S. manufacturing. ${ }^{37}$ Third, these industries operate large plants; they are concentrated in specific regions (in 1972, 66 percent of U.S. automobile employment was in the East North Central census region and 76 percent of steel employment in the East North Central and Middle Atlantic regions); and they are heavily

34. See Aho and Carney, "An Empirical Analysis of the Structure of U.S. Manufacturing Trade."

35. The high-technology products tend to have lower ratios of physical capital per employee. This has an important link to the Leontief paradox discussed above.

36. Except for race. For an analysis of the employment effects of trade on minorities see Robert Z. Lawrence, "Minority Employment and U.S. Trade," in Foreign Trade Policy and Black Economic Advancement (Joint Center for Political Studies, 1981), pp. 49-63.

37. Employment in the automobile industry itself (SIC 371) comprised 4.6 percent of employment in manufacturing in 1972 (Bureau of Labor Statistics). Using input-output analysis, I estimate that output in the automobile industry indirectly generated employment in the rest of manufacturing, and thus accounted for an additional 4.9 percent. 
Table 5. Some Characteristics of U.S. Manufacturing, High- and Low-Technology Industries, Computers, Automobiles, and the Steel Industry during the Past Two Decades $^{\mathrm{a}}$

\begin{tabular}{|c|c|c|c|c|c|}
\hline Item & $\begin{array}{l}\text { High- } \\
\text { tech- } \\
\text { nology } \\
\text { industry }\end{array}$ & $\begin{array}{l}\text { Low- } \\
\text { tech- } \\
\text { nology } \\
\text { industry }\end{array}$ & $\begin{array}{l}\text { Com- } \\
\text { puters }\end{array}$ & $\begin{array}{l}\text { Auto- } \\
\text { mobiles }\end{array}$ & Steel \\
\hline Employees (thousands) ${ }^{b}$ & $6,513.4$ & $13,771.6$ & 354.2 & 788.8 & 428.4 \\
\hline Black employees (percent) ${ }^{c}$ & 5.3 & 9.7 & 4.1 & 13.5 & 13.0 \\
\hline Women employees (percent) ${ }^{b}$ & 30.7 & 33.2 & 35.9 & 14.0 & 6.9 \\
\hline Production workers (percent) ${ }^{b}$ & 62.1 & 74.3 & 40.0 & 72.9 & 77.5 \\
\hline \multicolumn{6}{|l|}{$\begin{array}{l}\text { Employees covered by collective bargaining } \\
\text { (percent) }^{\mathrm{d}}\end{array}$} \\
\hline All workers & 38.9 & 49.0 & 11.0 & 72.0 & 77.0 \\
\hline Production workers & 58.2 & 61.5 & 15.0 & 98.0 & 98.0 \\
\hline Median number of school years completed ${ }^{c}$ & 12.5 & 11.6 & 13.7 & 12.1 & 12.0 \\
\hline Median age in years ${ }^{\mathfrak{c}}$ & 38.9 & 40.3 & 32.6 & 39.3 & 43.7 \\
\hline Work force stability (percent of workers & & & & & \\
\hline employed $50-52$ weeks) ${ }^{c}$ & 76.8 & 70.4 & 79.5 & 70.9 & 77.8 \\
\hline Average hourly wage of production workers & & & & & \\
\hline $\begin{array}{l}\text { (dollars) }^{\mathrm{b}} \\
\text { Average annual compensation of all workers }\end{array}$ & 7.62 & 7.12 & 6.73 & 9.85 & 11.84 \\
\hline (dollars) $^{\mathrm{b}}$ & 22,300 & 18,800 & 23,000 & 30,300 & 34,100 \\
\hline Capital-labor ratio (dollars) ${ }^{b}$ & 23,700 & 30,790 & 21,600 & 40,200 & 93,400 \\
\hline Labor's share (percent) ${ }^{\mathrm{b}}$ & 51.9 & 50.3 & 47.7 & 70.8 & 73.8 \\
\hline Large-plant percentage & 41.4 & 23.6 & 58.5 & 71.5 & 89.4 \\
\hline Concentration ratio (percent) & 42.8 & 36.4 & 44.0 & 82.0 & 45.0 \\
\hline \multicolumn{6}{|l|}{$\begin{array}{l}\text { Allocation of employment by geographical } \\
\text { census regions (percent) }\end{array}$} \\
\hline Middle Atlantic & 21.4 & 20.5 & 18.6 & 8.8 & 32.9 \\
\hline New England & 10.0 & 6.6 & 12.1 & 1.2 & 0.4 \\
\hline East North Central & 28.8 & 24.7 & 4.6 & 65.9 & 42.7 \\
\hline West North Central & 6.2 & 6.0 & 14.0 & 6.7 & 1.3 \\
\hline South & 19.6 & 32.1 & 13.4 & 11.5 & 16.5 \\
\hline West & 14.0 & 10.1 & 37.3 & 6.0 & 6.1 \\
\hline
\end{tabular}

Sources: Annual compensation, capital-labor ratio, and share of labor are from U.S. Bureau of the Census, 1980 Annual Survey of Manufactures, M80 (A5)-5 (September 1982); race, school years, age, and work force stability are from Bureau of the Census, 1970 Census of Population (U.S. Government Printing Office, 1973); concentration ratios and regional employment are from the Bureau of the Census, 1972 Census of Manufactures (GPO, 1975) and 1977 Census of Manufactures (GPO, 1981), respectively; data on total employment, women, production workers, and average wages are from Bureau of Labor Statistics, Employment and Earnings, various issues; union coverage is from Richard B. Freeman and James L. Medoff, "New Estimates of Private Sector Unionism in the United States," Industrial and Labor Relations Review, vol. 32 (January 1979), pp. 143-74.

n.a. Not available.

a. The characteristics of high- and low-technology industries are based on a sample of three-digit 1970 census code industries that employed 85 percent of the employees in manufacturing in 1980. Employment figures for highand low-technology industries are from total manufacturing data (see figure 2). The Standard Industrial Classification (SIC) codes for computers, automobiles, and steel are 3573,371 , and 3312, respectively.

b. In 1980. Annual compensation includes social security and benefits. The capital-labor ratio is the gross book value of depreciable assets divided by employment. Labor's share is total employee compensation divided by value added.

c. In 1970. To derive median school years and median age I computed the weighted average (by number of employees) of the medians of men and women in the three-digit 1970 census-code industries.

d. From surveys of the $1968-72$ period.

e. In 1977 . The concentration ratio is the weighted average of the percent of output produced by the four largest companies in each four-digit Standard Industrial Classification (SIC) industry. The large-plant percentage is the percent of employees in establishments with 1,000 or more workers.

f. In 1972; Bureau of Census regions. 
unionized. Fourth, both employers and employees have considerable financial incentives to resist change. Workers earn large wage premiums that reflect advantages such as seniority benefits, monopoly rents, and the support of strong unions that they would not receive if employed elsewhere. ${ }^{38}$ And employers have invested unusually large amounts of capital per worker.

In most of these respects the computer industry is strikingly different. Its work force has considerably more white, female, educated, and young workers; it is much less unionized and is heavily concentrated in the western part of the United States. Thus if the "structural problem" of the reemployment of U.S. labor involves hiring automobile workers to build computers, as conventional wisdom appears to presume, the problem appears considerable. If, however, it involves a gradual replacement of low-technology jobs with high-technology jobs, it seems far more manageable. Considering that in November 1982 unemployed workers from primary metals and automobiles, many of whom are likely to be recalled, constituted, respectively, about 2.5 and 2.1 percent of total U.S. unemployment (and 9.1 and 7.7 percent of unemployment in manufacturing), the problems for these industries, while substantial for the individuals and firms involved, are a relatively small part of the overall story of U.S. manufacturing. ${ }^{39}$

\section{Conclusions}

In the 1970s the share of manufacturing employment in total U.S. employment continued its secular decline as a consequence of the revealed preference of U.S. consumers for services and the more rapid increase of productivity in the manufacturing sector.

Overall, U.S. industrial growth in the 1970s was sluggish but was almost precisely what would have been expected, given the slow growth

38. Compensation in steel and automobiles in 1980 was 53 and 36 percent higher, respectively, than in high-technology industries.

39. In 1980, employment in motor vehicles and equipment (SIC 371) and in blast furnaces and iron and steel foundries (SIC 331 and 332) amounted to 773,800 and 712,700, respectively. Together these industries accounted for about 16.2 percent of the decline in manufacturing employment from 1980 to 1982. 
in GNP. ${ }^{40}$ Nonetheless, the United States did not experience absolute deindustrialization in the 1970s. U.S. employment in manufacturing expanded, and given the growth rate of output, investment growth in manufacturing was remarkably rapid. In contrast to its decline from 1960 to 1973 , the share of manufacturing in total U.S. fixed business capital actually increased from 1973 to 1980.

The increase in U.S. manufacturing output since 1973 was about the same as the average of all industrial countries, and more rapid than in West Germany, France, and the United Kingdom. Although employment in U.S. manufacturing grew modestly, in every other major industrial market economy it declined. In fact, in virtually every major manufacturing sector employment in the United States grew faster than in Japan. In contrast to the U.S. experience, the share of total investment devoted to the manufacturing sector has declined in every major West European country. Although U.S. labor productivity growth in manufacturing was not as rapid as in other industrial countries, U.S. productivity levels in overall manufacturing remain the highest in the world.

From 1973 to 1980 , partly because of the real devaluations of the dollar, foreign trade provided a net addition to output and jobs in U.S. manufacturing. Although employment increases related to trade rarely exceeded 10 percent of total employment, those increases were widely diffused: of the fifty-two I-O industries in this study, for example, only eleven experienced employment declines due to trade during the 1973 to 1980 period.

The perceptions of an absolute decline in the U.S. industrial base and the belief that foreign competition has made a major contribution to that decline stem from the reinforcing effects of U.S. trade and domestic growth and the nature of adjustment difficulties associated with declines in industries adversely affected. The troubled industries are large and highly unionized, and the average plant is large. Workers displaced from several of these industries face the prospect of considerably lower wages.

The U.S. comparative advantage in skilled labor and standardized capital-intensive products has been declining secularly. And, because

40. A regression of industrial production on GNP and on a time trend fitted for 196073 yields a forecast of 1980 industrial production with great precision, using the actual value for GNP in 1980. 
of slow domestic growth, the domestic markets for those products have not expanded rapidly. But the U.S. comparative advantage in manufactured high-technology products has strengthened while the demand for high-technology products has grown relatively more rapidly in a climate of stagnation. In general, however, structural change in the U.S. economy during this period arose mostly from domestic factors.

In contrast to the performance in the 1970s, from 1980 to 1982 foreign trade contributed to the employment decline in manufacturing. The drop in employment due to exports was about a third of the total fall in employment in manufacturing. The recent developments should not be interpreted as a sudden diminution of U.S. comparative advantage in manufacturing, however. Rather, they are the direct consequence of the substantial erosion of the price competitiveness of U.S. products associated with the real appreciation of the U.S. dollar. While employment in high-technology industries has declined less rapidly than in lowtechnology industries in the current recession, the relation has been typical of recession behavior. Employment in both sectors should increase significantly with recovery from the recession.

\section{APPENDIX}

\section{Detailed Technical Data for Estimates and Classification Scheme}

The following tables present estimates and the classification scheme for changes in value added and employment resulting from foreign trade and domestic use by industry. 
Table A-1. Percentage Change in Value Added Resulting from Foreign Trade and Domestic Use, by the Fifty-two Input-Output Categories in U.S. Manufacturing, 1970-80 and 1973-80

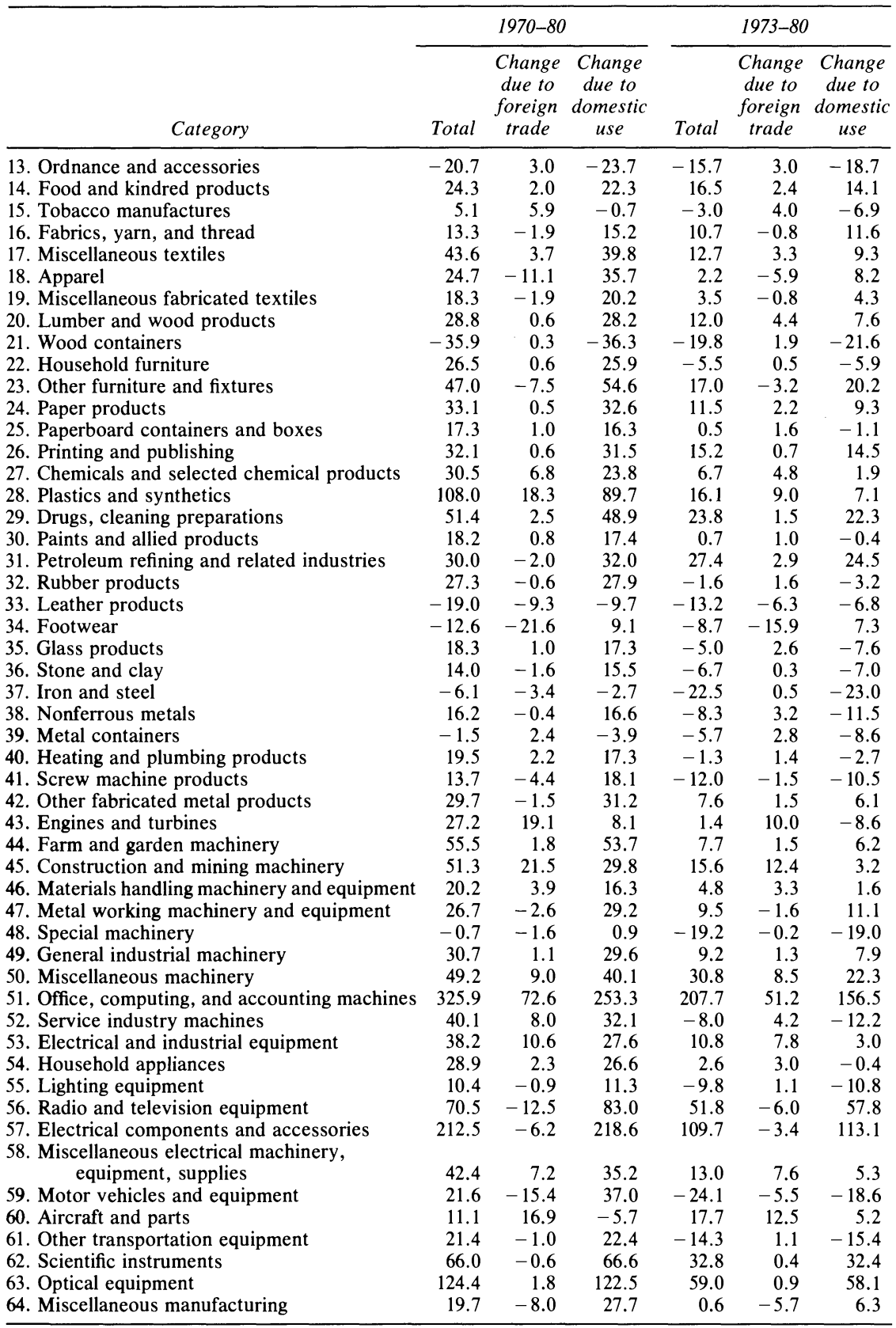

Sources: Same as table 1.

a. See Survey of Current Business, vol. 59 (February 1979), p. 54, for definitions of the I-O categories according to the SIC codes. 
Table A-2. Percentage Change in Employment Resulting from Foreign Trade and Domestic Use, by the Fifty-two Input-Output Categories in U.S. Manufacturing, 1970-80 and 1973-80

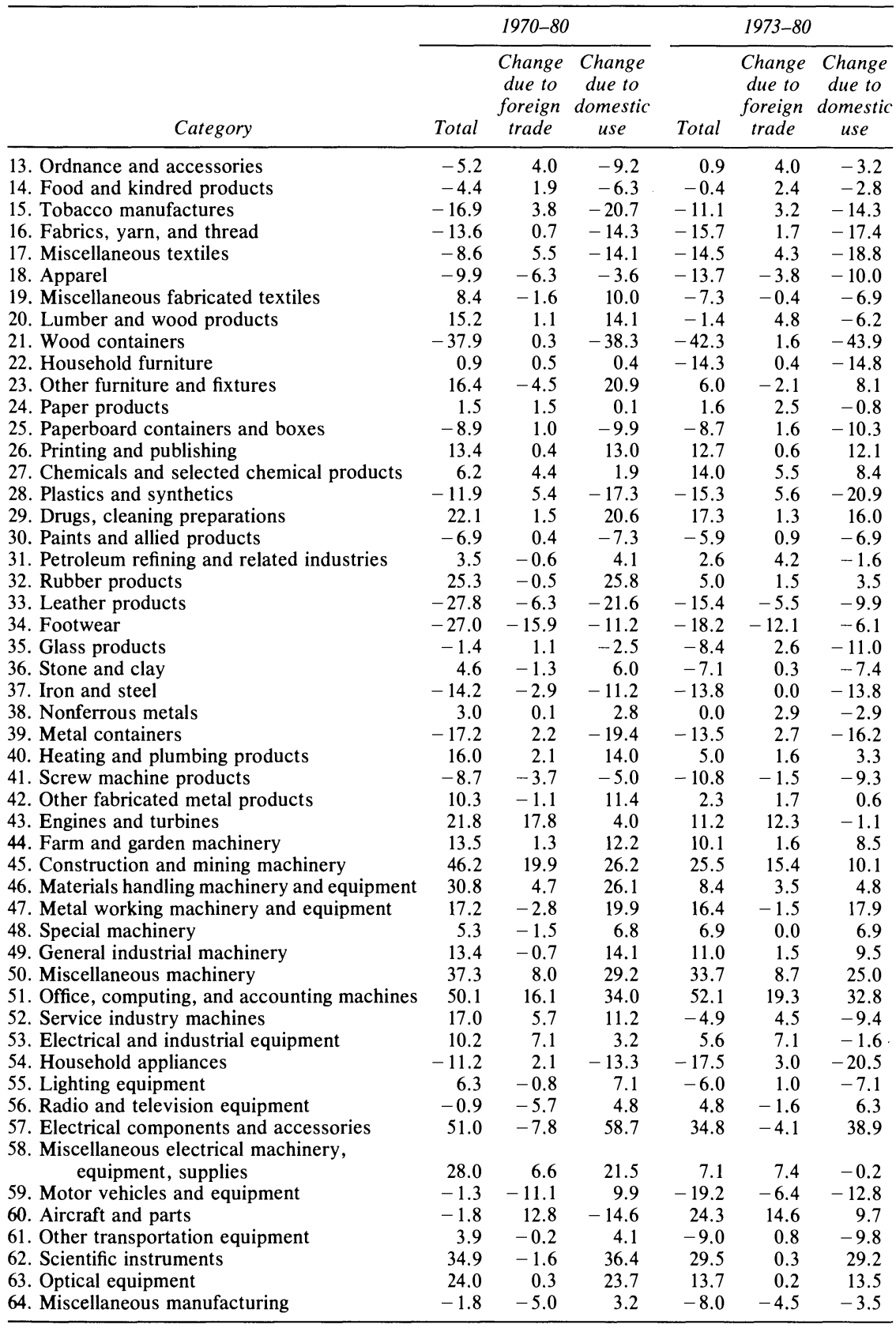

Sources: Same as table 1 .

a. See table A-1, note a. 


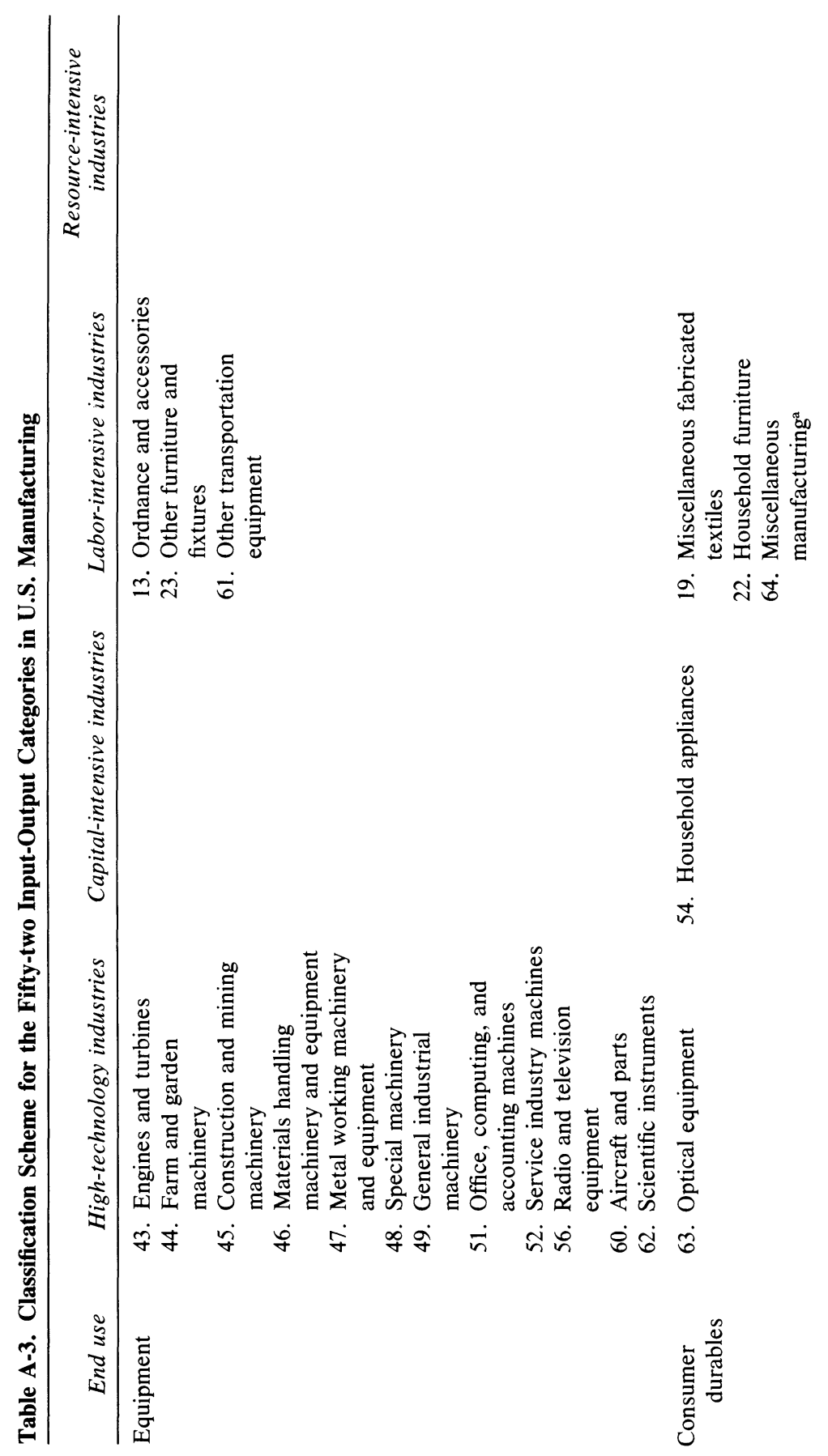




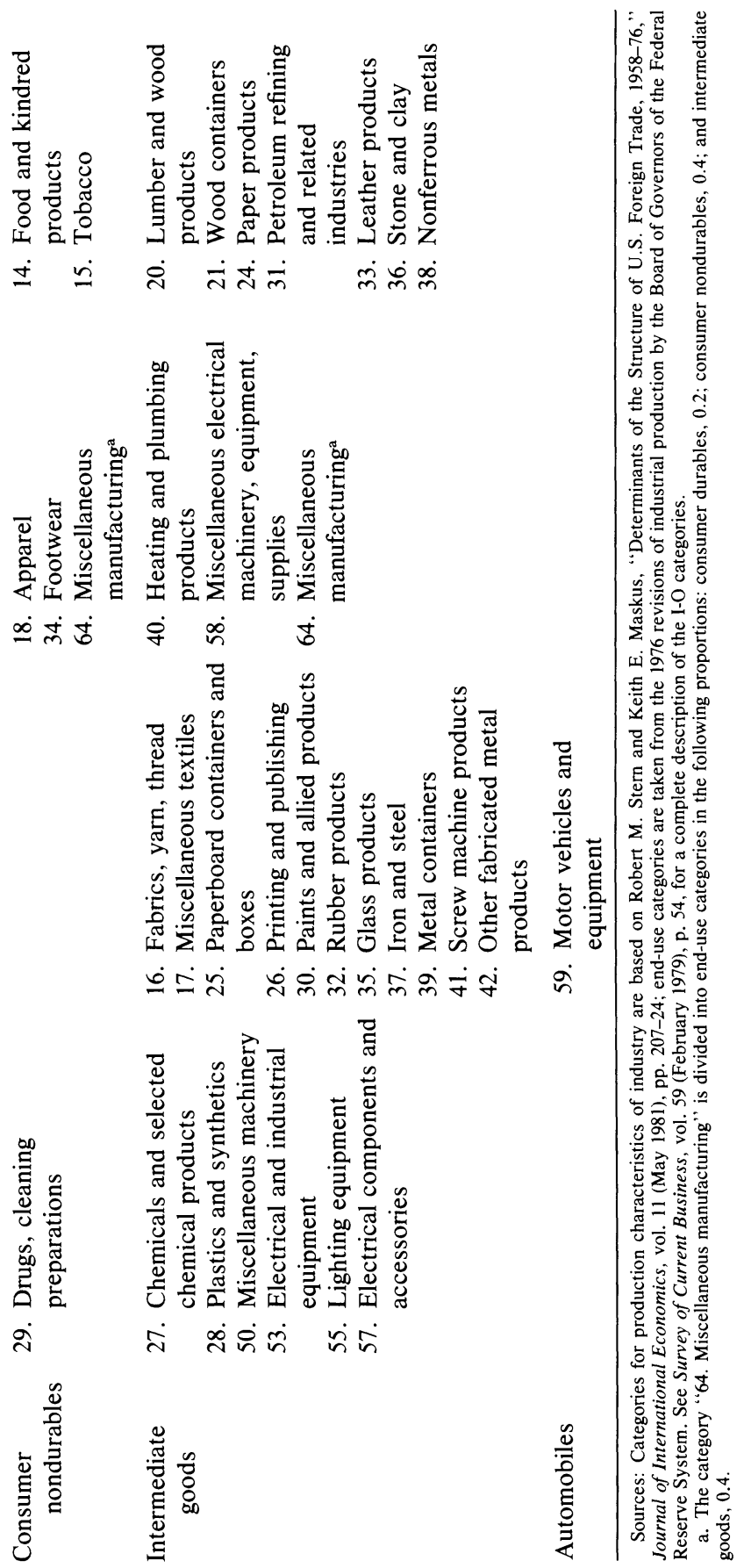




\section{Comments and Discussion}

Richard N. Cooper: I read Lawrence's paper with great interest. It is an extremely useful paper for correcting widespread misconceptions in public discussion of the changing industrial structure of the U.S. economy and the reasons for it. I like Lawrence's simple, comprehensible, almost old-fashioned direct analysis of the facts. I like it above all because his broad conclusions agree with my priors on the nature of changes in the U.S. economy and the relation between those changes and foreign trade-in particular, the conclusion that changes in the composition of domestic demand are a far more important source of change in the structure of output and employment than are changes in the pattern of foreign trade.

The point is made most dramatically in Lawrence's table A-2, which shows that domestic uses of output dominated the sectoral changes in employment during the 1970 s by a substantial margin. The major structural changes within manufacturing are domestic in origin, not foreign. Some changes, such as ordnance, reflect sharp shifts in domestic demand-in that case, government demand. Others reflect market changes in techniques of production-toward lower labor-output ratios, for instance.

It is true that cases can be found in which imports have had a major depressing effect on domestic employment (apparel is the standard example), although even here changes in techniques of production have been more important, as testified by the sharp increase in value-added for domestic use contrasted with a decline in employment.

But there are many other sectors-tobacco, miscellaneous textiles, and especially aircraft, for instance-in which the growth in foreign 
demand has served to reduce the declines in employment that would have occurred on the basis of domestic uses alone.

Apart from drawing attention to this central result, I make five observations: two on possible extensions of the paper, two on the possible qualifications to the paper, and one on a somewhat surprising apparent result in the paper and the possible reason for it.

The possible extensions involve both time and space. The first suggestion is to extend Lawrence's analysis backward in time, to cover the 1960s. Tables 2 and 4 give glimpses of the differences between the 1960s and the 1970s, and the glimpses are consistent with Lawrence's claim that the main difference between the two decades was the rate of growth of overall demand, with little difference in the rate at which the structure of manufacturing changed. In other words, structural change in U.S. manufacturing was no greater in the 1970s than it was in the 1960 s, once one corrects for overall demand. This is a strong and unconventional conclusion if substantiated by more detailed analysis, in particular by correcting for a change in the exchange rate, a point to which I return below.

A second extension would compare the results for the United States with what has happened in Europe. U.S. manufacturing employment rose almost 5 percent during the 1970s. In sharp contrast, manufacturing employment in the European Community fell by 12 percent. Does this difference reflect some important structural difference, such as downwardly rigid real wages in Europe, as Sachs suggests? Or is it merely the result of conjunctional differences at the beginning and end of the decade? Or, again, is it mainly due to changes in the real exchange rate of the dollar in terms of European currencies?

There are two major events that cloud Lawrence's results. He acknowledges both of them, but does not make much of either. It is fortuitous that 1970 and 1980 had roughly the same rates of utilization, and that is helpful for comparing those two years. By a widespread consensus, however, the dollar was overvalued in 1969 and, if anything, undervalued in 1979, years that would strongly influence the trade figures for 1970 and 1980, respectively. (The Morgan Guaranty index of the real effective exchange rate of the dollar shows a drop of 19 percent between 1970 and 1980.) Ideally, statements about structural change exclude or at least separate out presumably temporary misalignments of currencies 
from other factors. Many are inclined to accord little significance to changes in currency values, in keeping with our continuing determination to approach the U.S. economy as if it were closed, and then to make minor allowance for net exports. I would be inclined to give considerable weight to them, weight that is reinforced by the observation that the United States had a tremendous surge of net exports in 1978-80, following a sharp depreciation of the dollar, and that net exports in turn fell dramatically in 1980-82, following a marked appreciation of the dollar. Correction for these changes in exchange rates might lead Lawrence to qualify his results somewhat; but it would also suggest that some of what is attributed to structural factors is strongly subject to the influence of financial factors.

The other major change that took place in the 1970s was the sharp increase in oil prices, especially the increase of 1974. (The increase of 1979-80 may not have influenced Lawrence's results greatly.) The inputoutput coefficients that he uses are drawn from 1972 and therefore date from before the sharp rise in oil prices. It is not clear how these coefficients might have changed by the late 1970s; it depends on the energy-labor and energy-capital substitution possibilities and the time period associated with shifts to newer, energy-conserving techniques of production. Being deeply skeptical of the contention that capital and energy are complements, whereas labor and energy are substitutes, I cannot conclude that Lawrence's calculations are biased in any obvious way, except toward energy and the capital involved directly in the production of energy. But that deserves more attention than he has given to it: in any case, the effects will be discovered when new input-output coefficients become available.

My final observation focuses on table 5 and the problems of aggregation involved in studying the influence of technology on trade. Table 5 shows that the employees in low-technology industries are older and less well educated than those in high-technology industries, as is commonly believed. But the differences are very small, about one year in each case. These figures do not suggest that the economy dichotomizes neatly into industries in which employees are the old and poorly educated, and those in which employees are young and well educated. Moreover, they do not suggest a great increase in structural unemployment as the low-technology industries contract and the high technology ones expand. 
The greatest difference between the two categories involves the capital-labor ratio, and that works in a direction that is favorable to growth because lower amounts of capital are apparently required to employ labor more productively in the high-technology industries than in the low-technology ones.

However, there is good reason to doubt that the broad categories reported in table 5 capture adequately the differences between low- and high-technology activities. The data reported for two illustrative industries, steel and computers, do indeed show much greater differences in average age and educational attainment. But they also display some odd features. Their average hourly wages are respectively above and below the average wages for the broader categories, and the wage discrepancy between them can only be described as huge. These wage figures, taken naively, suggest that educational attainment has a negative return in the neighborhood of the averages, or else that seniority overwhelms educational attainment in determining one's wage. The discrepancy is so large as to suggest that wage differentials in this instance may far out weigh differences in technological prowess in determining economic performance.

But the more general point concerns the ultimate arbitrariness involved in classifying industries into broad categories. Nonferrous metals, for instance, are classified as resource-based, whereas iron and steel together are classified as capital intensive. Textiles are classified either as capital intensive or as labor intensive. Yet there have been tremendous technical improvements in textile fabrics over the past twenty years and, indeed, by 1980 the United States had become a net exporter of textiles, in part on the strength of these improvements. At the same time, much of the machinery and equipment industry, classified here as high technology, is quite traditional both in its manufacturing techniques and in its products. In actuality, high technology is potentially spread through all sectors of manufacturing-optical fibers as part of the glass industry is an example-and some firms are much more alert to the potential than others. I would conjecture that high technology plays an even greater role in U.S. trade performance than Lawrence's figures suggest. But two- or three-digit levels of classification are simply too coarse to capture accurately the full influence of new technology. 
George M. von Furstenberg: Before Robert Lawrence goes into the postwar history of comparative advantage in the United States, he provides exactly the kind of research data that sophisticated politicians, trade negotiators, and industry lobbyists could take into battle. Some of them might be disappointed that the numbers do not come out quite the way they had imagined. Lawrence may further deflate their claims when he stresses repeatedly that the development of the U.S. manufacturing sector would have been qualitatively the same without the effects due to foreign trade, so that there might not be much trade to complain about. Nevertheless, he reports inter alia that there was a decline of 10,000 jobs due to trade between 1970 and 1980 . This occurred despite the marked improvement in U.S. relative price competitiveness, which he ascribes to the dollar devaluations in 1971, 1973, and 1978-79. Because the dollar has appreciated sharply in real terms since 1979, it would be natural for someone to observe, as Lawrence does, that the rate of job loss due to trade has accelerated in the 1980s. Politicians generally know what to make of such presumptions even though economists do not.

It would not be the fault of the provider if factual information were misused for protectionist ends. Nevertheless, Lawrence does comparatively little to guard against misinterpretation of his partial-equilibrium results. I therefore see my role as helping to increase the supply of inhibitors. After some further exposition I attempt to do so by telling a Stolper-Samuelson story that may or may not fit recent external developments and their effects on the United States. The last step is then to ask how that story would be captured in Lawrence's input-output accounting framework or in the exercise with ex post data, as he calls it. If the story line does not survive this exercise and quite different accents emerge in the retelling, this could provide a substantial caution against reasoning from ex post data for policy purposes.

At the simplest level of the public debate about the employment effects of trade, the volume of imports and exports of the kind that would appear under particular three- or four-digit SIC codes, such as motorcycles (part of SIC code 375), is compared with the number of motorcycles sold in the United States. If net imports account for 50 percent of domestic sales and U.S. manufacturers of motorcycles employ 5,000 persons, then 5,000 jobs are said to have been lost on account of the cycle trade.

Compared with this kind of numerical inference, Lawrence's analysis 
is very much more sophisticated. Within the input-output framework he had the choice of basically two lines of approach: (1) had he been interested principally in what motorcycle imports (to continue the previous example) would do to employment generally, he could have allowed for the fact that employment is reduced not only in this particular import-competing industry but also in all the industries supplying inputs to it; (2) if, alternatively, he wished to focus not on what motorcycle imports did to employment generally but on what imports of manufactured goods generally did to employment in the motorcycle industry, he could proceed differently. Choosing (2), he could recognize that employment lost in that industry could be due not only to the importation of motorcycles but also of goods that would have used motorcycles and parts as inputs had they been produced at home. ${ }^{1}$

Although the first of these two approaches could be more directly useful in the argumentation of those who seek to restrict imports of particular products while paying lip service to the idea of free trade elsewhere, the author chose the second approach advisedly. In doing so he provided some obstacles to abuse, but not nearly enough in my view. After all, before all but the most alert audiences, politicians can get nearly as much mileage from saying that imports of manufactured goods cut so much employment from the automobile industry as they can by claiming that automobile imports caused the loss of so much employment generally. Something is seriously wrong with all such claims, as the following example may show.

Consider the case of a country with a capital-intensive export-oriented sector and a labor-intensive import-competing sector. If one assumes that foreign demand for the output of the capital-intensive sector increases, the result will be that the relative price of products of that sector and of the factor used most intensively in the sector rises. Desired capital-to-labor ratios fall in both sectors, and labor incomes decline not only relatively but absolutely. The increase in foreign demand for a home country's exportables will lead to an appreciation of the domestic currency in real terms. If imports and import-competing goods are less than perfect substitutes in home consumption, the decline in the relative

1. Although these indirect effects are likely to be unimportant in the present example, they can be quite important at the two-digit level of input-output divisions chosen by the author. 
price of imports will reduce, but normally not eliminate, the fall in the real consumption wage of labor. If the fall in the equilibrium level of the real wage creates temporary unemployment and unacceptable redistribution of income, there are familiar countermeasures that could be taken without restricting trade. Furthermore, the income effects arising from the improvement in the terms-of-trade and rate-of-return effects of the greater demand for capital will increase saving and add to the productive base of the economy. In the short-run, however, domestic use of the capital-intensive product will decline but by less than the rise in exports. Conversely, domestic use of the labor-intensive product will increase but by less than the rise in imports. Hence domestic production will shift from labor-intensive to capital-intensive goods while domestic absorption shifts in the reverse direction, with both exports and imports increasing. ${ }^{2}$

How would all this be reflected after the fact in the accounting framework described earlier in these comments? Lawrence would find that exports have contributed significantly to employment in the capitalintensive sector and more than offset the decline in employment stemming from the reduction in domestic use which is taken as given. $\mathrm{He}$ would further report that employment in the labor-intensive sector has been reduced by imports growing more than domestic use, with both changes again taken as given rather than induced. His sectoral casuistry notwithstanding, there has been only a single cause or shock from which all else followed in the above system: a rise in the foreign demand for exportables. It appears that less can be learned from Lawrence's tabulations than the presentation of his results suggests.

There are some other difficulties of interpretation. For instance, inputoutput analysis is not particularly discerning of the national destination of incomes from trade. Surely it makes a difference if exports from the United States are produced by foreign-owned firms, if U.S. exports are displaced by the output of U.S.-owned manufacturing facilities abroad, or if imports to the United States are obtained from foreign subsidiaries or branches of U.S. corporations. The stream of factor-service incomes

2. Under the reverse circumstances, increases in imports will have both direct and indirect (general equilibrium) effects on exports, as described by Walter S. Salant, "The Effects of Increases in Imports on Domestic Employment: A Clarification of Concepts," Special Report 18 (Washington, D.C.: The National Commission for Manpower Policy, January 1978), pp. 15-23. 
generated from past capital exports has implications for the balance of trade in manufactured goods and the interpretation of any measured employment loss that could arise from a negative balance. Mature creditors are supposed to have such balances for international compatibility. Finally, trade in automobiles, shoes, steel, and textiles, to name but a few, has not been free for a long time and is becoming progressively more restricted. ${ }^{3}$ Miscreants who do not believe in exchange-rate effects of trade restrictions in equilibrium might even argue that the reason why Lawrence does not find larger employment losses from trade in these and other industries is precisely because import restrictions have worked so well. ${ }^{4}$

\section{General Discussion}

Hendrik Houthakker questioned the value of looking only at the effect of trade on the manufacturing sector. The agricultural and service sectors are also heavily involved in international trade. For example, the United States is a major exporter of soybeans, both raw beans and meal or oil. If soybeans are exported as meal or oil they would be included in Lawrence's analysis, but otherwise they would be excluded. From the point of view of employment, however, the distinction between these forms is unimportant.

Edward Bernstein observed that by simply comparing the increase in manufactured exports with the increase in manufactured imports over

3. Net trade restriction in some categories, such as automobiles, is difficult to measure since some countries in this hemisphere also restrict U.S. automobile exports through domestic value-added or reexport requirements that constrain their balance of net imports of automobiles and parts from the United States.

4. For recent work analyzing effects on trade in conditions of general equilibrium with or without instant clearing in labor markets and for further references : $\rightarrow$ Andrew Feltenstein, "A General Equilibrium Approach to the Analysis of Trade Restrictions, with an Application to Argentina," IMF Staff Papers, vol. 27 (December 1980), pp. 749-84; Fred Brown and John Whalley, "General Equilibrium Evaluations of Tariff-Cutting Proposals in the Tokyo Round and Comparisons to More Extensive Liberalization of World Trade," Economic Journal, vol. 90 (December 1980), pp. 838-66; and Alan V. Deardorff and Robert M. Stern, "A Disaggregated Model of World Production and Trade: An Estimate of the Impact of the Tokyo Round," Journal of Policy Modeling, vol. 3 (May 1981), pp. 127-52. See also a survey article by John B. Shoven and John Whalley on "Applied General Equilibrium Models of Taxation and International Trade,"'Journal of Economic Literature (forthcoming). 
the 1970s, Lawrence has ignored the fundamental change in world trade brought about by higher oil prices. The increase in oil prices induced OPEC nations to increase enormously their importation of manufactured goods. Industrial countries in general were thus compelled to have bigger increases in their manufactured exports than in their manufactured imports simply in order to finance higher energy bills. In addition, when industrial nations pay higher prices for oil, these imports absorb expenditure and hold down demand for manufactured and other domestic goods because there is no rise in domestic income to offset the rise in energy bills. For these reasons, the overall effect of foreign trade on employment cannot be inferred by an analysis that is confined to manufactured goods. Bernstein also pointed out that much of the rise and then decline in U.S. net exports of goods and services, in constant dollars, has been attributable to changes in factor income, such as profits and interest earned on American foreign investments. Although variations in real net exports are often used in explaining domestic developments, fluctuations arising from factor income are largely irrelevant in assessing the net effect of trade on U.S. employment.

Houthakker also wanted to know more about income and substitution effects, which are crucial for extrapolating trends in manufacturing trade into the future. He emphasized the need to account for the effects of the dollar devaluations and revaluations on foreign demands for U.S. exports. This is especially important in the near term because of the recent great strengthening of the dollar which, by many measures, has carried the dollar exchange rate above its level in 1970. Bernstein argued, however, that the big drop in U.S. manufacturing exports since 1981 has been due to the severe world recession. The recession has affected the United States more seriously than Europe because a larger fraction of U.S. exports is bought by the developing countries that are most adversely affected by the downturn.

C. Fred Bergsten questioned Bernstein's interpretation of the effect of the world recession. Although world demand for U.S. exports has fallen, the domestic recession has reduced U.S. demand for foreign goods at the same time. He concluded that, on balance, the net impact of the recession has not been large either in helping or hurting the U.S. trade balance. Bergsten also suggested that the impact of trade on employment during certain subperiods of the past decade was especially instructive. During 1978-80, U.S. exports grew at double the rate of 
world trade generally and actually recaptured all the share of world exports of manufactured goods that the United States had lost after the late 1960s. The chief reason for this return to competitiveness was the elimination of the dollar overvaluation of the preceding period. U.S. experience during $1978-80$ provides a powerful rebuttal to the view that the nation is being deindustrialized due to a fundamental loss of ability to compete. 